\title{
Molecular Detection of Cucumber Mosaic Virus and Tobacco Mosaic Virus Infecting African Nightshades (Solanum scabrum Miller)
}

\author{
S. L. Kimaru $\mathbb{D}^{1},{ }^{1}$ D. C. Kilalo $\mathbb{D}^{1},{ }^{1}$ W. M. Muiru $\mathbb{D},{ }^{1}$ J. W. Kimenju $\mathbb{D}^{1},{ }^{1}$ and C. R. Thuku $\mathbb{D}^{2}$ \\ ${ }^{1}$ Department of Plant Science and Crop Protection, University of Nairobi, P.O. Box 30197, Nairobi, Kenya \\ ${ }^{2}$ Kenya Plant Health Inspectorate Service (KEPHIS), P.O. Box 49592-00100, Nairobi, Kenya
}

Correspondence should be addressed to S. L. Kimaru; samuelklinguya@gmail.com

Received 17 August 2020; Revised 28 September 2020; Accepted 23 October 2020; Published 6 November 2020

Academic Editor: Anshu Alok

Copyright (c) 2020 S. L. Kimaru et al. This is an open access article distributed under the Creative Commons Attribution License, which permits unrestricted use, distribution, and reproduction in any medium, provided the original work is properly cited.

\begin{abstract}
The two viruses cucumber mosaic virus (CMV) and tobacco mosaic virus (TMV) are among the major viruses that constrain the production of African nightshade (ANS). The ANS provides high proportions of micronutrient content and has medicinal, economic, and agronomic benefits. In this study, we utilized molecular methods to detect these viruses present in ANS at two locations in Kenya: Kisii and Kakamega counties. Ribonucleic acid (RNA) was extracted from leaves of ANS plants exhibiting viral symptoms and sequenced on the Illumina MiSeq platform for phylogenetic studies. The isolates were grouped based on nucleotide and sequence identity. We detected two isolates of CMV and one isolate of TMV in ANS samples. The isolate sequences have been deposited in the GeneBank to obtain accession numbers. Cucumber mosaic virus nucleotide sequence closely resembled the Kirinyaga isolates in Kenya classified in subgroup I. Tobacco mosaic virus phylogenetic studies revealed close resemblance of isolates KY810785.1 from Britain and AF273221.1 from the USA in clade 1 based on nucleotide and amino acid sequences. This is an indication that the virus is widely distributed across the world. Detection of these two viruses in Kenya suggests that they are prevalent in crop-growing regions and the germplasms. African nightshade could also act as a virus reservoir infecting other plants. This study will inform management options to prevent virus epidemics and be in control of vectors.
\end{abstract}

\section{Introduction}

African nightshade is a vital crop cultivated in Western, Eastern, and Southern Africa as well as in India, Indonesia, and China [1]. The crop is rich in protein, vitamin A, iron, and calcium. It is commonly sold in major supermarkets and greengrocery stores as a leafy vegetable in most African countries [2]. The ANS vegetable crop is grown in both highland and lowland areas in most African countries [3]. In Kenya, the consumption has increased tremendously and the African leafy vegetables now account for $30 \%$ of all vegetables sold in the market [4]. Viral diseases lead to yield and crop quality losses. Two viruses CMV and TMV have been found as the main epidemic viruses in many parts of Kenya and on different crops [5]. Limited information is available on the incidence and prevalence of these viruses on
ANS. However, there is adequate research concerning these viruses on other solanaceous crops especially tomato and potato.

To date, CMV isolates are classified into subgroups I and II according to their serological relationships and nucleotide sequence identity [6]. Based on recent reports, CMV subgroup I was found to be predominant in tropical and subtropical regions [7]. Tobacco mosaic virus belongs to the genus Tobamovirus and family Virgaviridae [8]. Tobamoviruses are transmitted through mechanical contact and at a low percentage through seed and not by insect vectors [9]. The typical viral symptoms are veinal necrosis, mosaic, mottling, yellowing, deformation, shoestring, ring spots, and stunting [10]. Today, new techniques based on DNA analysis have been used and proven to be efficient due to high specificity and sensitivity [11]. Due to its great potential, over 
the past 20 years, many PCR-based assays have been reported for the identification of viral pathogens [12]. The molecular tools have promoted efforts to set up assays with specific technical aspects (e.g., specificity, sensitivity, and robustness) and economical demands (e.g., short diagnosis time, high-throughput, minimum taxonomic expertise, and minimum cost) [13]. Next-generation sequencing allows phylogenetic analyses of the complete genome in order to obtain a representative set of sequences reflecting the diversity of strains and geographical distribution [14]. Sequence alignments are performed, gaps and missing data are removed, and rate variation among sites is estimated using gamma distribution [15]. The objective of this study was to detect CMV and TMV infecting ANS in Kenya to understand their distribution as a basis for their management. Information concerning the occurrence of these viruses in ANS and their potential viruses' reservoirs is lacking; hence, there is a need for this study. We hypothesize that CMV and TMV are the major viruses occurring in ANS and constrain its production.

\section{Materials and Methods}

2.1. Research Sites. African nightshade leaf samples showing virus-like disease symptoms were collected from the sampling sites. These sites are Suneka and Ogembo in Kisii, Lurambi, and Amalemba in Kakamega, Kenya. A global positioning system was used to locate the sites. Suneka is located at a latitude of $0^{\circ} 40^{\prime} 43.5^{\prime \prime} \mathrm{S}$ and a longitude of $34^{\circ}$ $42^{\prime} 27.7^{\prime \prime} \mathrm{E}$ in upper midland zones AEZ UM 2. The average annual rainfall is $800-1000 \mathrm{~mm}$, temperature ranges from 18 to $21^{\circ} \mathrm{C}$, and altitude ranges between 1500 and 2000 meters above sea level (a.s.l.). Ogembo is located at a latitude of $0^{\circ}$ $50^{\prime} 18.8^{\prime \prime} \mathrm{S}$ and a longitude of $34^{\circ} 43^{\prime} 47.6^{\prime \prime} \mathrm{E}$ in lower highlands zones AEZ LH 2. The average annual rainfall is $1300-1600 \mathrm{~mm}$, temperatures range from 15 to $18^{\circ} \mathrm{C}$, and altitude ranges from 2000 to $2500 \mathrm{~m}$ a.s.l. Amalemba is located at a latitude of $0^{\circ} 16^{\prime} 14.4^{\prime \prime} \mathrm{N}$ and a longitude of $34^{\circ}$ $45^{\prime} 14.6^{\prime \prime} \mathrm{E}$ in upper midlands zone AEZ UM 4. The altitude range is $1500-1900 \mathrm{~m}$ a.s.l, rainfall is between 1000 and $1600 \mathrm{~mm}$, and temperature ranges from 18 to $21^{\circ} \mathrm{C}$. Lurambi is located at a latitude of $0^{\circ} 17^{\prime} 42.5^{\prime \prime} \mathrm{N}$ and a longitude of $34^{\circ}$ $4^{\prime} 47.9^{\prime \prime} \mathrm{E}$ in the lower midlands AEZ LM 2. The altitude range is $1300-1500 \mathrm{~m}$ a.s.l, rainfall ranges from 1500 to $1800 \mathrm{~mm}$, and temperatures range from 20 to $22^{\circ} \mathrm{C}[16,17]$.

2.2. Source of Virus Isolates. Leaf material samples (the youngest trifoliate leaves) obtained from 24 plants at each location were flash-frozen in liquid nitrogen and transported to the laboratory at the Kenya Plant Health Inspectorate Service on dry ice for processing.

2.3. Total RNA Extraction. Total RNA was extracted from the plant leaves using the Trizol protocol (Thermo Fisher, Waltham MA). Briefly, it involved extraction and purification of total RNA using Trizol reagents, homogenization of cell suspensions, separation of tissues, RNA precipitation, RNA wash, dissolving the RNA, and determination of RNA concentration and purity. The protocol was used in the extraction of RNA for all the samples. Finally, the purified RNA was stored at $-20^{\circ} \mathrm{C}$ in a freezer.

2.4. cDNA Production and RT-PCR. Total purified RNAs for TMV and CMV were used for complementary DNA (cDNA) synthesis using a PCR kit (GoTaq, Promega, USA). cDNA was synthesized and incubated following manufacturers' instructions (GoTaq, Promega, USA). Reverse primer for each specific virus was used during synthesis (Table 1). The synthesized cDNA was diluted $1: 4$ with $\mathrm{ddH}_{2} \mathrm{O}$ and stored at $-20^{\circ} \mathrm{C}$ awaiting PCR. The polymerase chain reaction was used to amplify the $3^{\prime}$ terminal genomic region of the virus using degenerate primers (Table 1). Cucumber mosaic virus and tobacco mosaic virus PCR was performed in a $25 \mu \mathrm{l}$ of a reaction mixture prepared following the manufacturers' protocol (Qiagen, USA).

2.5. Next-Generation Sequencing (NGS). Twenty four samples used earlier were pooled into 14 combinations based on the agroecological zones for sequencing. Fourteen purified PCR products each $15 \mu \mathrm{l}$ per tube and 12 primers each $10 \mu \mathrm{l}$ per tube were prepared. Ribosomal RNA was depleted with the kit ribo-Zero rRNA removal kit (Illumina, USA), and the RNA integrity number was measured in a 2200 bioanalyzer (Agilent Technologies, USA). The cDNA library was constructed with the TrueSeq RNA sample preparation kit (Illumina, USA) and NGS performed in Illumina MiSeq 2010 equipment at Inqaba Biotechnology and Genomics Company (South Africa).

2.6. Bioinformatics Analysis. After NGS, low-quality bases were removed from the data set. Sequences from CMV and TMV were identified using BLASTN against a local database containing all viruses infecting plants in the ninth report of the International Committee of Taxonomy of Viruses [10]. The nucleotide sequences of the gene were aligned with those of corresponding viruses deposited in GenBank by using Clustal-LC software. Sequence homology analyses of the gene were performed using Bio-Edit version 7 software. Viral genomes were assembled to reference genomes. Assemblies were verified for inconsistencies and sequencing errors with tablet open reading frames (ORFs) identified using BLASTN. The phylogenetic tree was constructed using MEGA 7.0 software with the neighbor-joining algorithm and 1000 bootstrap replications. Consensus sequences for CMV and TMV were submitted to GenBank to obtain accession numbers.

\section{Results}

3.1. Viral Leaf Symptoms. The leaf samples obtained from the field had a variety of visible symptoms that were associated with virus infection. These symptoms included yellow-green mosaic, stunting, rugosity, vein clearing, yellowing, leaf curling, and wilting (Figures 1(a)-1(d)). 
TABLE 1: Nucleotide sequences of oligonucleotide primers used for molecular testing, genomic locations, and target viruses in African nightshades.

\begin{tabular}{|c|c|c|c|}
\hline Primers & Sequence $\left(5^{\prime}-3^{\prime}\right)$ & Product size & Target strain \\
\hline $\begin{array}{l}\mathrm{CV}(\mathrm{F}) \\
\mathrm{CV}(\mathrm{R})\end{array}$ & $\begin{array}{l}\text { GCCACCAAAAATAGACCG } \\
\text { ATCTGCTGGCGTGGATTTCT }\end{array}$ & $593 \mathrm{bp}$ & Cucumber mosaic virus (CMV) \\
\hline $\begin{array}{l}\text { TMV (F) } \\
\text { TMV (R) }\end{array}$ & $\begin{array}{l}\text { CGATGATGATTCGGAGGC } \\
\text { GAGGTCCARACCAAMCCAG }\end{array}$ & $512 \mathrm{bp}$ & Tobacco mosaic virus (TMV) \\
\hline
\end{tabular}

Note. The full-length primer sequences for the specific virus were sourced from the NCBI nucleotide database and manually aligned in a text editor. The primer design software Prifi [18] was used to select primers. CMV: cucumber mosaic virus; TMV: tobacco mosaic virus; F: forward primer; R: reverse primer; $\mu$ l: microliters.

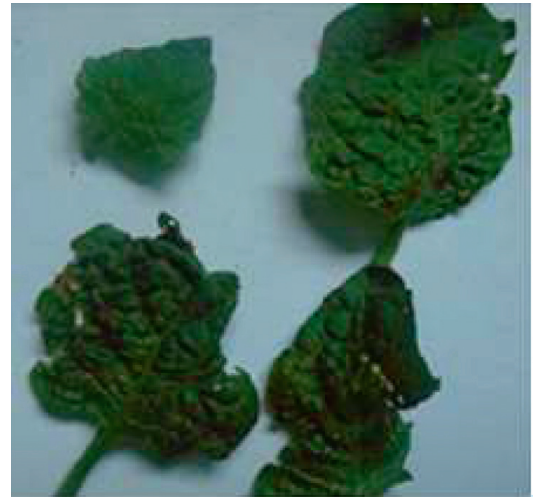

(a)

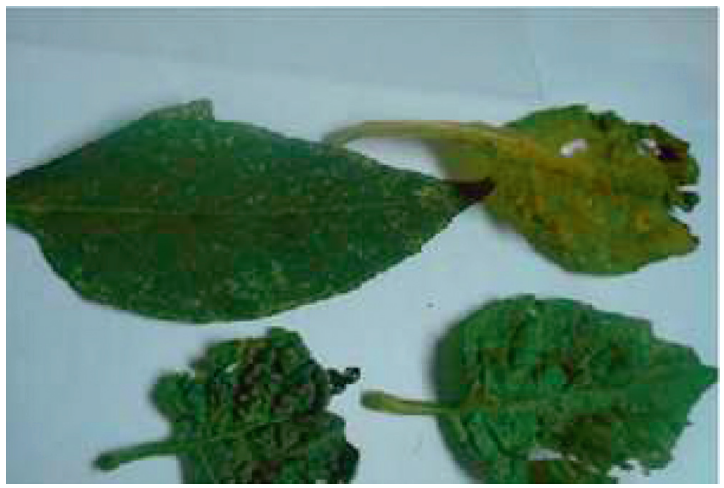

(c)

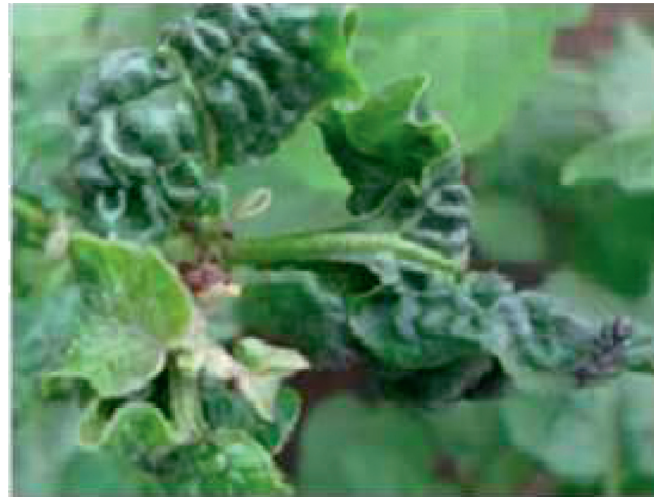

(b)

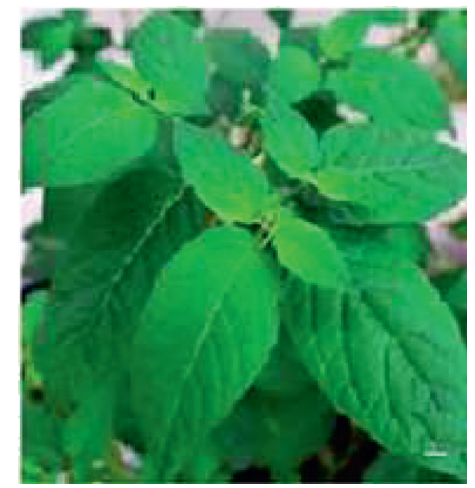

(d)

Figure 1: ((a)-(d)) Leaf viral-like symptoms in African nightshade observed in the field. (a) Leaf rugosity. (b) Leaf curling. (c) Leaf malformations. (d) A healthy African nightshade plant.

\subsection{Detection of Cucumber Mosaic Virus in African} Nightshade. African nightshade leaf samples tested positive (Figure 2). Half of the samples from the four sites were positive for the Cucumber mosaic virus. Ogembo and Amalemba had more samples positive for CMV at $67 \%$ compared to Suneka and Lurambi recording 33\%. The virus was present in the four agroecological sites (Figure 2)

\subsection{Phylogenetic Studies of Cucumber Mosaic Virus in African} Nightshade. Neighbor-joining phylogenetic analysis based on full-length viral genomes was performed with a bootstrap of 1000 replications. The genomic sequence of the $10 \mathrm{CMV}$ isolates (Figure 3) shared genes of 86 and $100 \%$ identity with the Kenyan

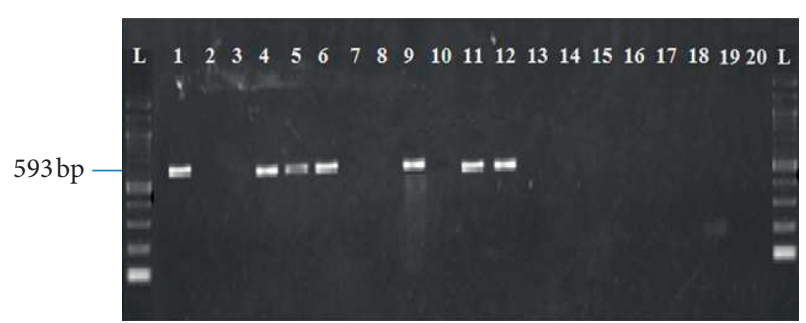

Figure 2: Detection of Cucumber mosaic virus in African nightshade leaves from farm fields in different agroecological zones using RT-PCR. L-DNA ladder. Samples 3, 7, and 11: Suneka; 4, 8, and 12: Ogembo; 5, 9, and 13: Amalemba; 6, 10, and 14: Lurambi; 2: healthy control; 1: positive control. $\mathrm{CMV}=593 \mathrm{bp}$ 


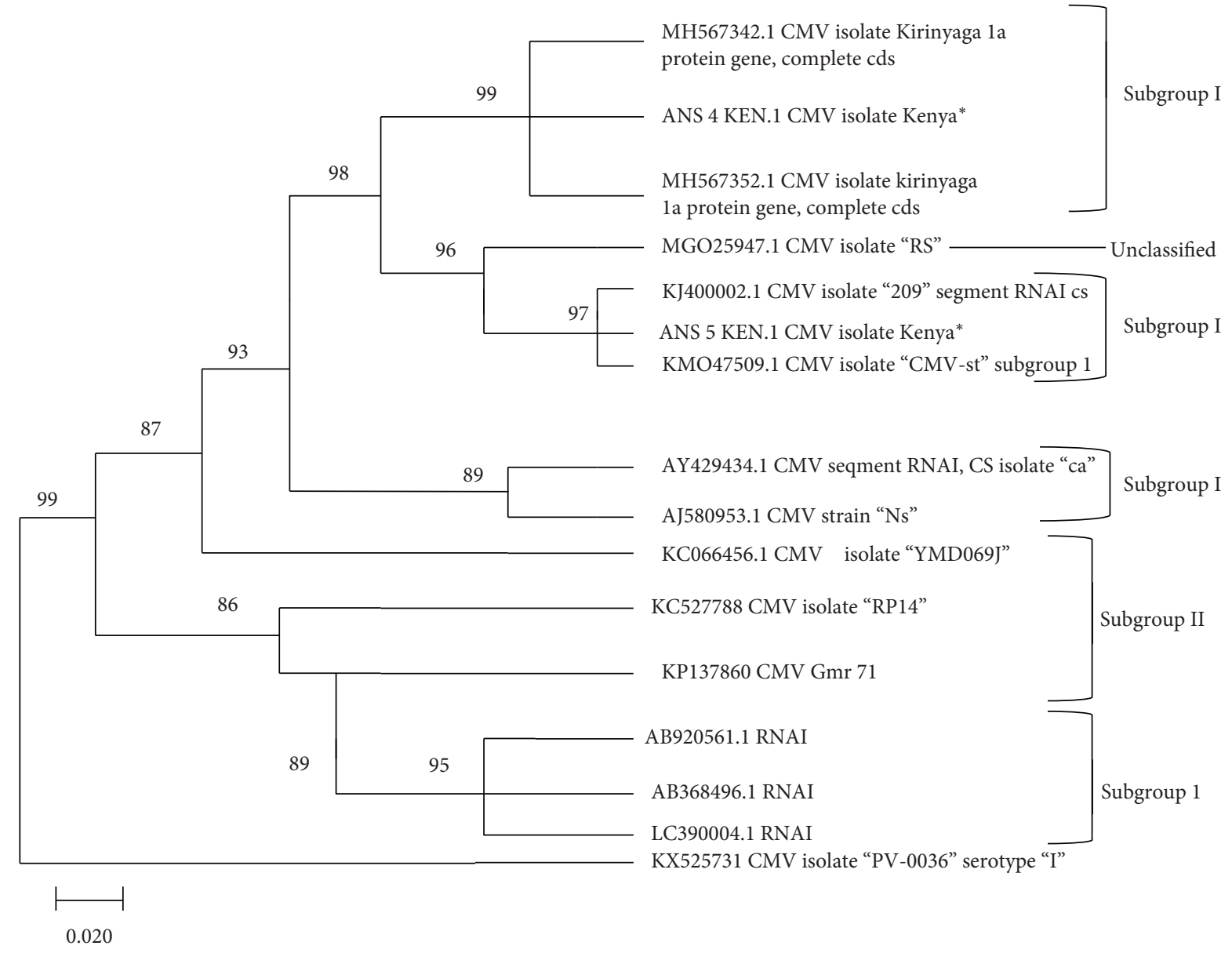

FIgURE 3: Phylogenetic analysis of Cucumber mosaic virus (CMV) isolates, with aligned nucleotide sequences, generated using the neighborjoining method and MEGA6 software. The percentage of replicate trees in which the associated taxa clustered together in the bootstrap test (1000 replicates) is shown next to the branches. "Kenyan ANS isolates. The tree was rooted using KX525731 CMV Isolate "PV-0036" serotype "I" as an outgroup sequence for the phylogenetic analysis.

isolates. The isolates were grouped into groups according to the percentage sequence identity. The ANS isolates were homologous to 10 isolates belonging to subgroup I, three isolates in subgroup II, and one isolate unclassified (Figure 3). Two Kenyan CMV isolates from Kirinyaga under accession numbers (MH567342.1 and MH567352.1) had the highest similarity of $99 \%$ and belong to subgroup I. The ANS isolates had a similarity of 96\% with MGO25947.1 isolate "RS" from China, KJ400002.1 isolate "209" from South Korea, and KMO447509.1 from South Korea. In addition, it had 89\% similarity AYA429434.1 isolate "ca" from China and AJ580953.1strain "Na" from Hungary in Subgroup I. Isolates L066456, KC527788, and KP137860 had $87 \%$ similarity and placed in subgroup II. CMV KC527788 isolate "RP14" from South Korea and KP137860 from Brazil had $86 \%$ similarity (Figure 3 ).

3.4. Detection of Tobacco Mosaic Virus in African Nightshade. Seven pooled leaf samples from agroecological zones UM4, LH2, LM2, and UM2 were positive for Tobacco mosaic virus (TMV) (Figure 4). More than half of the samples tested from UM2 (14 and 10), LH2 (17 and 9), and UM4 (16 and 8) representing $67 \%$ of the pooled samples were positive for

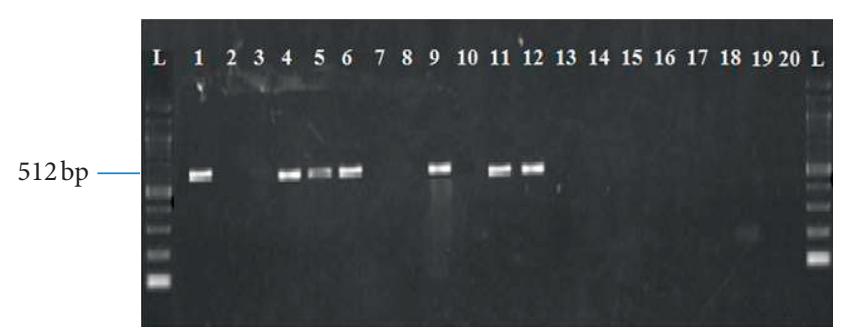

Figure 4: Detection of Tobacco mosaic virus in leaf samples of African nightshade in different agroecological zones using RTPCR. L-DNA ladder. Samples 18, 14, and 10: UM2; samples 17, 13, and 9: LH2; samples 16, 12, and 8: UM4; samples 15, 11, and 7: LM2; 19: healthy control; 20: positive control. TMV = $512 \mathrm{bp}$.

TMV. Samples from LM2 had the lowest viral load recording $33 \%$ compared to other sites (Figure 4).

3.5. Phylogenetic Studies of Tobacco Mosaic Virus in African Nightshade. The phylogenetic analysis with TMV Kenyan isolates confirms the distribution of this plant virus worldwide. TMV KY810785.1 strain FERA 111011 from 


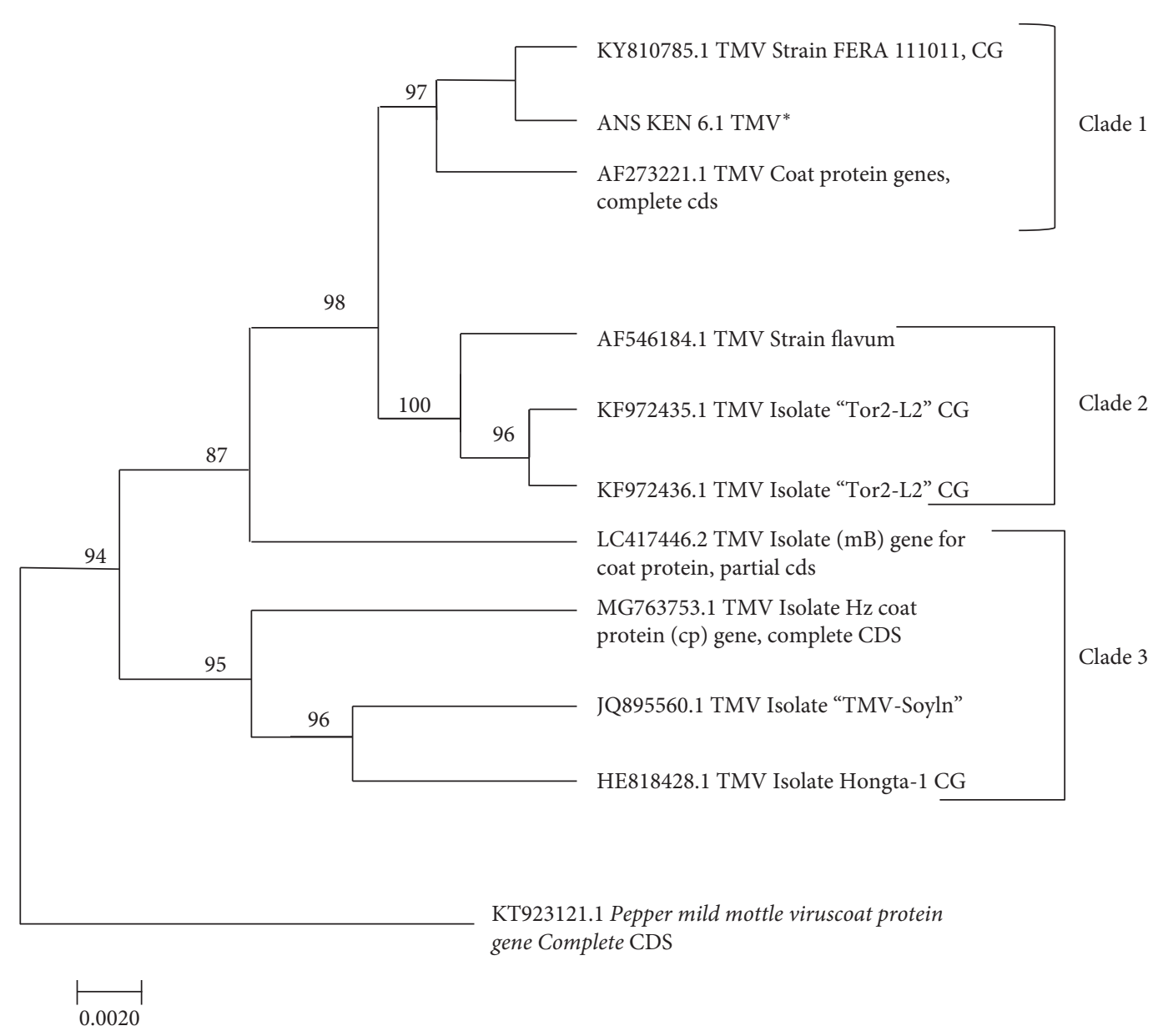

FIgURE 5: Phylogenetic analysis of Tobacco mosaic virus (TMV) isolates, with aligned nucleotide sequences, generated using the neighborjoining method and MEGA6 software. The percentage of replicate trees in which the associated taxa clustered together in the bootstrap test (1000 replicates) is shown next to the branches. ${ }^{*}$ Kenyan ANS isolates. The tree was rooted using Pepper mild mottle virus (PMMoV) as an outgroup sequence for the phylogenetic analysis.

Britain formed clade 1 with TMV AF273221.1 from the USA and the Kenyan ANS isolate with 97\% identity. CMV KF972435.1 TMV isolate "Tor2-L2" from Spain, AF546184.1 from Finland, and KF972436.1 from Spain formed clade 2 and were 96\% homologous with Kenyan ANS isolate. In addition, TMV MG763753.1 isolate $\mathrm{Hz}$ from China is clustered with isolates TMV JQ895560.1 “TMV-Soyin” from India and TMV HE818428.1 Hongta-1 from China with 95\% homology and formed clade 3. Finally, TMV KT923121.1 Pepper mild mottle virus from Brazil was used as an outgroup sequence (Figure 5).

\section{Discussion}

This study has demonstrated that African nightshade is a host to Cucumber mosaic virus (CMV) and Tobacco mosaic virus (TMV). These viruses were detected in symptomatic African nightshade leaves obtained from farm fields in the agroecological zones using molecular techniques. Although data on the pathogenic potential of the viruses is not readily available, intensive cultivation of the crop might lead to building up inoculum to levels beyond the economic threshold. The detection of these viruses concurs with studies done on other solanaceous crops like potato, tomato, and tobacco [19]. Cucumber mosaic virus belongs to the genus Cucumovirus with $60-65 \%$ strains identity and is one of the most common plant viruses of major agricultural significance [20]. It is a tripartite virus having three plus sense, single-stranded RNA molecules encased in separate particles [20]. The Kenyan isolates revealed up to 86 to $96 \%$ similarity to 10 isolates worldwide. Kenyan CMV isolates caused variable symptoms, including necrotic or chlorotic lesions, mild to severe mosaic, stunting, leaf deformation, and shoestring formation. Similar symptoms were reported by [21]. Phylogenetic analysis revealed isolate homology with 10 different isolates of CMV from Kenya, China, South Korea, South Africa, and Brazil at the nucleotide level. Based on phylogenetic analysis, the CMV isolate in this study was found to be closely related to those of South Korea and China. This study reports a high prevalence of the virus in Kenya and a similar report by [22] concurs. Based on the phylogenetic tree, the isolates under the current investigation could be classified in subgroup I. Subgroup I strains show severity in terms of symptom and disease development 
in tobacco [23]. Similar reports show CMV subgroup I to be competitive in its infection on different host plants [23].

Tobacco mosaic virus belongs to the genus Tobamovirus and has a very wide host range; it can cause a serious economic impact in many crop families such as cucurbits, brassicas, solanaceous, and ornamental plants [24]. The infected plants showed different types of symptoms which included mosaic, malformation, mottle, and stunting. Tobacco mosaic virus infections have been reported in Kenya on solanaceous crops but there are no reports on African nightshade [24]. Phylogenetic analysis of TMV in African nightshade isolates revealed its wide distribution in agroecological zones (UM2, LH2, UM4, and LM2) with $67 \%$ of the samples analyzed using RT-PCR testing positive for TMV. It was closely related to isolates from European and Asian countries showing a worldwide distribution. Reference [25] also reported the worldwide distribution of TMV. Tobacco mosaic virus identified in the current study is closely related to those isolated from tobacco, tomato, and potato. TMV strains have a genetic variation in different hosts and environmental conditions [26]. Tobacco mosaic virus can perpetuate itself through germplasm. Similar studies have reported that Tobamovirus can easily be transmitted mechanically through seed and contact between plants, but not transmitted by a vector [25], and that debris can be an important source of inocula in the fields [19].

This study deployed molecular techniques for the detection of viruses associated with edible African nightshade. That was in recognition of the difficulties of using symptoms to identify viruses that usually occur in multiple infections under field conditions.

\section{Conclusion}

Cucumber mosaic virus and tobacco mosaic virus were frequently isolated viruses infecting African nightshade, and phylogenetic analysis revealed that they are closely related to similar viruses isolated worldwide. Cucumber mosaic virus caused necrotic and severe mosaic in edible African nightshade. Tobacco mosaic virus manifested mosaic, malformation, and mottling. Phylogenetic analysis revealed a close resemblance of two viruses to isolates from solanaceous crops. Molecular methods can be utilized by seed companies and phytosanitary bodies for the screening of seeds before certification. Detection of diseases in plant material especially seeds is essential to ensure safe and sustainable crop production.

\section{Data Availability}

The datasets used in the present study are available from the corresponding authors upon reasonable request.

\section{Conflicts of Interest}

The authors declare that there are no conflicts of interest.

\section{Acknowledgments}

The National Research Fund-Kenya and the University of Nairobi are acknowledged for providing facilities and funding this study.

\section{References}

[1] E. A. Olet, M. Heun, and K. A. Lye, "African crop or poisonous nightshade; the enigma of poisonous or edible black nightshade solved," African Journal of Ecology, vol. 43, no. 2, pp. 158-161, 2005.

[2] M. O. Abukutsa-Onyango, Strategic repositioning of African indigenous vegetables in the Horticulture Sector Résumé, in Proceedings of the Second RUFORUM Biennial Meeting, Ruforum Publication, Entebbe, Uganda, pp. 1413-1419, September 2010.

[3] D. M. Musyimi and J. Muthoni, "Growth responses of African nightshades (Solanum scabrum) seedlings to water deficit," Journal of Agricultural and Biological Science, vol. 4, no. 5, pp. 8-16, 2009.

[4] C. O. Ojiewo, G. N. Mwai, M. O. Abukutsa-Onyango, S. G. Agong, and R. Nono-Womdim, "Exploiting the genetic diversity of vegetable African nightshades," Biodiversity and Bioavailability, vol. 7, no. 1, pp. 6-13, Global Science Books, Carrollton, GA, USA, 2013.

[5] K. Mumbi, N. Karanja, M. Njenga, M. Kamore, C. Achieng, and P. Ngeli, Investigative Market Research: Viable Market Opportunities and Threats for Urban and Peri-Urban Farmers, Farm Concern International, Urban Harvest and International Potato Centre, Nairobi, Kenya, 2006.

[6] P. Palukaitis, M. J. Roossinck, R. G. Dietzgen, and R. I. B. Francki, "Cucumber mosaic virus," Advances in Virus Research, vol. 41, pp. 281-348, 1992.

[7] A. Haase, J. Richter, and F. Rabenstein, "Monoclonal antibodies for detection and serotyping of cucumber mosaic virus," Journal of Phytopathology, vol. 127, no. 2, pp. 129-136, 1989.

[8] M. J. Adams, J. F. Antoniw, and J. Kreuze, "Virgaviridae: a new family of rod-shaped plant viruses," Archives of Virology, vol. 154, no. 12, pp. 1967-1972, 2009.

[9] N. J. Spence, I. Sealy, P. R. Mills, and G. Foster, "Characterization of a Tobamovirus from trailing petunias," European Journal of Plant Pathology, vol. 107, no. 6, pp. 633-638, 2001.

[10] C. Kerlan, O. V. Nikolaeva, X. Hu, T. Meacham, S. M. Gray, and A. V. Karasev, "Identification of the molecular make-up of the potato virus $Y$ strain PVY (Z): genetic typing of PVY (Z)-NTN," Phytopathology, vol. 101, no. 9, pp. 1052-1060, 2011.

[11] I. C. Paylan and M. Gumus, "Detection of viruses in seed of some vegetables by reverse transcriptase polymerase chain reaction (RT-PCR)," African Journal of Biotechnology, vol. 12, no. 25, pp. 3891-3897, 2013.

[12] R. Z. Ahmed, I. A. M. Ibrahim, H. M. S. Hassan, and D. A. ELWakil, "Incidence of Potato virus $Y$ strains and effect of infection on the productivity of potato tubers," Journal of Agriculture and Veterinary Science, vol. 2, pp. 58-64, 2013.

[13] B. Lievens and B. P. H. J. Thomma, "Recent developments in pathogen detection arrays: implications for fungal plant pathogens and use in practice," Phytopathology, vol. 95, no. 12, pp. 1374-1380, 2005.

[14] L. Liu, J. Xie, J. Cheng, Y. Fu, G. Li, and X. Yi, "Fungal negative-stranded RNA virus that is related to bornavirus and 
nyavirus," Proceedings of Natural Sciences Academies U.S.A., vol. 111, pp. 205-210, 2014.

[15] P. A. Gutiérrez, J. F. Alzate, and M. A. Marín-Montoya, "Complete genome sequence of a novel potato virus $S$ strain infecting Solanum phureja in Colombia," Archives of Virology, vol. 158, no. 10, pp. 2205-2208, 2013.

[16] FAO/UNESCO, Revised Legend for the Soil Map of Kenya, World Soil Resources Report, Rome, Italy, 2000.

[17] R. Jaetzold, H. Schmidt, B. Hornet, and C. Shisanya, Farm Management Handbook of Kenya, vol. II/C1, Ministry ofAgriculture, Kenya and German Agency Technical CooperationTeam (CTZ), Nairobi, Kenya, 2006.

[18] J. Fredslund, L. Schauser, L. H. Madsen, N. Sandal, and J. Stougaard, "Using a multiple alignment of related sequences to find primers for amplification of homologs," Nucleic Acids Research, vol. 33, pp. 516-520, 2005.

[19] B. A. Coutts and R. A. C. Jones, "Potato virus Y: contact transmission, stability, inactivation, and infection sources," Plant Disease, vol. 99, no. 3, pp. 387-394, 2015.

[20] M. Jacquemond, "Cucumber mosaic virus," Advances in Virus Research, vol. 84, pp. 439-504, 2012.

[21] M. Rabie, C. Ratti, M. Calassanzio, E. A. Aleem, and F. A. Fattouh, "Phylogeny of Egyptian isolates of Cucumber mosaic virus (CMV) and Tomato mosaic virus (ToMV) infecting Solanum lycopersicum," European Journal of Plant Pathology, vol. 149, no. 1, pp. 219-225, 2017.

[22] J. M. Mutuku, F. O. Wamonje, G Mukeshimana et al., "Metagenomic analysis of plant virus. occurrence in common bean (Phaseolus vulgaris) in Central Kenya," Frontiers in Microbiology, vol. 9, p. 29, 2018.

[23] T. Tungadi, S. C. Groen, A. M. Murphy, A. E. Pate, J. Iqbal, and T. J. A. Bruce, "Cucumber mosaic virus and its $2 \mathrm{~b}$ protein alter emission of host volatile organic compounds but not aphid vector settling in tobacco," Virology Journal, vol. 14, p. 91, 2017.

[24] S. Kumar, A. C. Udaya Shankar, S. C. Nayaka, O. S. Lund, and H. S. Prakash, "Detection of Tobacco mosaic virus and Tomato mosaic virus in pepper and tomato by multiplex RT-PCR," Letters in Applied Microbiology, vol. 53, no. 3, pp. 359-363, 2011.

[25] F. Wang, S. Qi, Z. Gao, I. A. Akinyemi, D. Xu, and B. Zhou, "Complete genome sequence of tobacco virus 1, a closterovirus from Nicotiana tabacum," Archives of Virology, vol. 161, no. 4, pp. 1087-1090, 2016.

[26] T. Ho and I. E. Tzanetakis, "Development of a virus detection and discovery pipeline using next generation sequencing," Virology, vol. 471-473, pp. 54-60, 2014. 